\title{
Nutrient uptake and yield performance of cassava in two compost amended soils $\mathbf{s}^{1,2}$
}

\author{
Gustavo A. Martínez $z^{3}$, Miguel A. Vázquez", Agenol González, \\ Luis E. Rivera ${ }^{6}$, and José L. Guzmán ${ }^{4}$
}

J. Agric. Univ. P.R. 85(1-2):17-32 (2001)

\begin{abstract}
The effects of a sewage sludge compost on the nutritional status and crop performance of cassava (Manihot esculenta, PI 12095) were evaluated on a Mollisol (Cumulic Haplustolls) and an Ultisol (Aquic Haplohumults) of Puerto Rico. Compost rates evaluated were $0,33.5,67,134$, and 402 t/ha. At its highest rate, compost additions caused a reduction in yield in Corozal. Moreover, the addition of compost increased the number of non-commercial roots. It is suspected that such effects were due to the highly saline nature of the compost. The nutritional status of the plants was minimally affected by the compost. Significant effects were observed only at the highest treatment: an increase in uptake in the case of nitrogen, phosphorus and potassium, and a decrease in the amount of magnesium and iron uptake. An evaluation of the nutrient distribution among different plant tissues revealed that nitrogen, phosphorus, magnesium, calcium, and zinc were concentrated mostly in the leaves, whereas potassium and iron were concentrated mostly in the root peel. Cadmium was the only element exhibiting equal or higher concentration in the pulp tissue than in the peel. This finding substantiates the potential for cadmium to enter the human food chain and emphasizes the need to monitor the concentration of this element in soils where cassava is to be grown.
\end{abstract}

Key words: Cassava, nutrient uptake, sewage sludge compost, tropical soils

\section{RESUMEN}

Rendimiento y absorción de nutrimentos de la yuca en dos suelos enmendados con composta

Los efectos de una composta de cieno sanitario sobre el estado nutricional y productividad de la yuca (Manihot esculenta, PI 12095) se evaluaron en un Mollisol (Cumulic Haplustolls) y en un Ultisol (Aquic Haplohumults) de

${ }^{1}$ Manuscript submitted to Editorial Board 1 September 1999.

${ }^{2}$ The authors are grateful to Dr: Raúl E. Macchiavelli, Associate Professor of the College of Agriculture, for his assistance with the statistical analyses. This project was supported by the U.S.D.A. Tropical and Subtropical Agricultural Research Program.

${ }^{3}$ Associate Soil Chemist, Agricultural Experiment Station, University of Puerto Rico, P.O. Box 21360, San Juan, P.R., 00928 (For correspondence).

${ }^{4}$ Laboratory Technician, Department of Agronomy and Soils, Agricultural Experiment Station, Río Piedras, P.R.

${ }^{5}$ Associate Researcher, Department of Horticulture, Agricultural Experiment Station, Corozal, P.R.

${ }^{6}$ Associate Researcher, Department of Agronomy and Soils, Agricultural Experiment Station, Juana Díaz, P.R. 
Puerto Rico. Los niveles de composta evaluados fueron: $0,33.5,67,134, y$ 402 tha. En su nivel más alto la composta causó una reducción en producción en Corozal. Además, las adiciones de composta causaron un incremento en el número de raíces no comerciales. Se estima que dichos efectos fueron causados por la naturaleza altamente salina de la composta. El estado nutricional de las plantas no sufrió cambios significativos con los diferentes niveles de composta. Sólo con el nivel más alto de composta se observó un efecto notable, evidenciando un aumento en la cantidad de nitrógeno, fósforo, y potasio absorbida por las plantas y una disminución en la absorción de magnesio y hierro. Una evaluación de la distribución de los nutrimentos en diferentes tejidos vegetativos reveló que el nitrógeno, fósforo, magnesio, calcio, y zinc estaban mayormente concentrados en las hojas, mientras que el potasio y el hierro se concentraban mayormente en la cáscara de las raíces. Cadmio fue el único elemento cuya concentración en la pulpa de la raíz excedió la concentración de la cáscara. Este resultado resalta el potencial del cadmio para entrar en la cadena alimenticia humana, y confirma la necesidad de limitar la concentración de este elemento en suelos donde se siembra yuca.

\section{INTRODUCTION}

The potential introduction of pathogens and contaminants into the human food chain, as well as the impact that such constituents may have on the integrity of natural ecosystems, is the biggest obstacle for the implementation of large-scale land application programs of sewage sludge products. To address this issue, the U.S. Environmental Protection Agency (USEPA) established a regulation setting limits for a series of pollutants and requiring that certain management practices be adopted to ensure that sewage sludge is handled and applied in ways that protect the public and the environment (USEPA, 1993). Opponents to this rule question the risk-analysis process on which the contaminant limits were based and caution against the potential deleterious long-term effects of the regulation (McBride, 1995). Specifically, critics point out the following:

- The USEPA 503 rule is essentially based on short-term experiments at relatively low metal loading rates, and thus long-term effects of established limits are unpredictable.

- The 503 rule makes no allowance for differences in soil and sludge chemistry, all of which may hinder this rule's effectiveness on a broad scale.

- The risk analysis process upon which this regulation is based relied heavily on data from experiments with corn, which is one of the least sensitive crops to copper $(\mathrm{Cu})$ and zinc $(\mathrm{Zn})$ toxicity. This low sensitivity may have resulted in higher allowable values than what would be safe for other crops, or for soil microbiota. 
- Plant toxicity estimates were based on information from plant top tissues (shoots, leaves), neglecting for the most part effects on roots.

The above mentioned factors become particularly relevant in non-traditional U.S. agricultural systems such as those of Puerto Rico, where a significant portion of the soils available for agriculture are highly weathered and the crops of major economic importance are semi-perennial or perennial in nature. Not only do these crops experience a more prolonged exposure to the growing media than the indicator crops utilized in the 503 rule (e.g., corn, lettuce) but their edible portion may not hold any physiological equivalence to those utilized in the establishment of the EPA regulation. That is the case of cassava (Manihot esculenta Crantz), a root crop that is a major contributor of the calories consumed by the inhabitants of the humid tropics (Irizarry and Rivera, 1983). Most of the soils on which cassava is grown suffer from low productivity due either to the effects of extensive erosion, low natural fertility or unfavorable climatic conditions (e.g., extensive drought periods). The application of organic-rich materials such as animal manure or sewage sludge derived products has become a common practice in those soils (Hulugalle et al., 1990). These materials not only serve as a source of nutrients but also improve the physical properties of the growing media, all of which generally translates into greater productivity. This investigation was prompted by the lack of information on contaminant uptake by root crops, as well as by the scarcity of data on crop performance and nutrient dynamics in tropical soils amended with sewage sludge products.

\section{MATERIAISS AND METHODS}

The study began in August 1996 on two research farms located in different ecological zones of Puerto Rico. Localities were Corozal, in the central mountainous region of the island (soil-Corozal series, Aquic Haplohumults), and Juana Díaz, on the south coast (soil-San Antón series, Cumulic Haplustolls). The sewage sludge compost used in this study was obtained from the Solid Waste Management Compost Facility in Arecibo. Five experimental treatments were evaluated in a randomized complete block design with four replicates. Treatments were $0,33.5,67,134$, and $402 \mathrm{t} / \mathrm{ha}$ of compost. Treatments 2,3 , and 4 were applied annually for a three-year period, and the $402 \mathrm{t} / \mathrm{ha}$ treatment was applied only once to evaluate the effect of single vs. continuous applications of compost. Results presented in this paper correspond to the first year of the experiment. 
Each experimental plot was $77.6 \mathrm{~m}^{2}(8.51 \mathrm{~m}$ by $9.12 \mathrm{~m})$, with 1.52 $\mathrm{m}$ border rows between plots. Compost rates were applied uniformly to the experimental plots and incorporated in the top $15 \mathrm{~cm}$ of soil. Stem cuttings of cassava (Manihot esculenta, PI 12095) were planted 30 days after treatment incorporation, $0.92 \mathrm{~m}$ apart in ridge rows spaced at $1.22 \mathrm{~m}$, or about 9,000 plants per hectare. In total, there were seven rows per plot, each row with 10 plants. Harvest data were obtained from 32 plants located in the center four rows of each plot 10 months after planting. A uniform fertilizer program was used regardless of the treatment since the compost was considered to be mainly a source of organic matter. A 6-6-12 fertilizer was used, according to recommendations established by the Agricultural Experiment Station (1997). Plant tissue samples (leaves, root peel, root pulp) were obtained four months after planting and at harvest. Leaf samples were obtained from the third leaf from the top, and root samples (peel, pulp) were obtained from the centers of the roots. Samples were analyzed for total element content (Dumas, 1989). At harvest, root production was classified as commercial and non-commercial according to visual standards.

Analyses of variance were conducted to evaluate the effect of compost on yield and nutrient status of the cassava plants. This approach was selected in favor of an evaluation of polynomial effects (linear and quadratic) since it was considered that the complex nature of the interactions between factors would complicate the interpretation of results. In the case of nutrient uptake, the statistical analyses included an evaluation of a model with four factors: location (Juana Díaz vs. Corozal), compost rates $(0,33.5,67,137$ and $402 \mathrm{t} / \mathrm{ha}$ ), time (four months, harvest), and plant tissue (leaves, root peel, root pulp). For most of the variables $(\mathrm{N}, \mathrm{P}, \mathrm{Ca}, \mathrm{Mg}, \mathrm{K}, \mathrm{Zn}, \mathrm{Fe}, \mathrm{Cu}, \mathrm{Cd}, \mathrm{Na})$ the effects were very complex, yielding highly significant 3 - and 4-way interactions among all factors (data not shown). The next step in the analyses consisted in evaluating significant differences among means. Given the complex nature of the interactions present, the following comparisons were made:

1) Comparisons between treatments at each location, time and plant tissue.

2) Comparisons between locations at each time and plant tissue (averaged through treatments).

3) Comparisons between times at each location and plant tissue (averaged through treatments).

Fisher's LSD tests were conducted to evaluate the means. Those means not significantly different $(0.05)$ within each group are presented here accompanied by the same letter. In addition, stepwise regression and 
correlation analyses were performed to relate plant element uptake to different soil parameters. Detailed information on soil parameters can be found in Martínez et al. (1999).

\section{RESULTS}

The effects of compost on the chemical and physical properties of the soils are discussed elsewhere (Martínez et al., 1999). Compost additions did not exert a significant effect on crop yield except for the highest treatment, which caused a reduction at Corozal (Table 1). A similar effect was observed in Juana Díaz for the same treatment but the effects were not statistically significant. There was a trend for an increase in root production in the mid compost treatments $(33,67$, and $134 \mathrm{t} / \mathrm{ha}$ ), especially in Juana Díaz, but the effects were not significant. Yield production estimates obtained four months after planting exhibited a similar pattern (Table 1), thus indicating that the effects associated with compost additions were expressed early in crop development. The number of non-commercial roots increased as a result of compost additions at both sites, although the effects were not statistically significant at Juana Díaz. This increase in non-marketable roots did not come at the expense of a reduction in the number of commercial roots, except in Corozal's highest treatment. In other words, compost

TABLE 1.-Effect of compost addition on cassava production.

\begin{tabular}{lcccc}
\hline $\begin{array}{c}\text { Treatment } \\
\text { (t/ha) }\end{array}$ & $\begin{array}{c}\text { Estimated yield } \\
\text { at } \begin{array}{c}\text { 4 months } \\
\text { (t/ha) }\end{array}\end{array}$ & $\begin{array}{c}\text { No. of } \\
\text { commercial } \\
\text { roots/plant at } \\
\text { harvest }\end{array}$ & $\begin{array}{c}\text { No. of non- } \\
\text { commercial } \\
\text { roots/plant } \\
\text { at harvest }\end{array}$ & $\begin{array}{c}\text { Yield at harvest } \\
\text { (t/ha) }\end{array}$ \\
\hline $\begin{array}{c}\text { Corozal } \\
0\end{array}$ & 4.99 & $5.03 \mathrm{~b}$ & $2.56 \mathrm{a}$ & $22.65 \mathrm{~b}$ \\
33.5 & 8.09 & $4.59 \mathrm{~b}$ & $4.31 \mathrm{~b}$ & $21.30 \mathrm{~b}$ \\
67 & 8.02 & $5.50 \mathrm{~b}$ & $4.47 \mathrm{~b}$ & $23.06 \mathrm{~b}$ \\
134 & 6.11 & $5.10 \mathrm{~b}$ & $4.96 \mathrm{~b}$ & $23.17 \mathrm{~b}$ \\
402 & 4.04 & $2.55 \mathrm{a}$ & $5.47 \mathrm{~b}$ & $11.04 \mathrm{a}$ \\
& $n \mathrm{~ns}$ & $\mathrm{LSD}=1.37$ & $\mathrm{LSD}=1.45$ & $\mathrm{LSD}=5.40$ \\
Juana Díaz & & & & \\
0 & 7.16 & 4.64 & 3.95 & 16.87 \\
33.5 & 7.45 & 4.85 & 5.75 & 18.32 \\
67 & 10.57 & 5.50 & 4.45 & 21.46 \\
134 & 8.18 & 4.65 & 5.29 & 19.73 \\
402 & 8.11 & 4.26 & 5.19 & 15.84 \\
& $n s$ & $n s$ & $n s$ & $n s$ \\
\hline
\end{tabular}


additions caused an increase in total root production per plant, but those were mainly of low commercial value. We believe that this finding could be related to the effects of compost on soil salinity, and the subsequent impact of soil salinity on root development. Compost additions raised the electrical conductivity of the soils to values close to what is considered limiting to crop performance (Martínez et al., 1999).

\section{Nutrient Uptake}

Fertilizer requirements of cassava plants grown on Puerto Rican soils are not clear. Fox et al. (1975) reported significant responses to nitrogen in some soils; however, Samuels (1969) found no response to nitrogen, but instead found phosphorus and potassium to be important. Fertilizer needs will certainly vary depending on factors such as soil type, cultivar, and climatic conditions prevalent during the growing stages. However, the fact remains that cassava is known for its ability to grow fairly well in soils of low fertility, and thus lack of response to nutrient additions in some soils is not rare. Irizarry and Rivera (1983) found no response of cassava grown on a Corozal clay soil to three different fertilizer levels $(0,500,1,000 \mathrm{~kg} / \mathrm{ha})$ of a $10-5-20-3$ formulation. The authors found no differences in the nutritional content of different plant tissues (leaves, stems, roots), thus inferring that fertilizer additions were unnecessary.

The effect of compost on nutrient and contaminant uptake was ascertained by analyzing different plant tissues (leaf, root pulp, and root peel) at two developing stages, four months and ten months (harvest) after planting. For the sake of simplicity, only the results obtained at harvest are shown (Tables 2 and 3). The nitrogen content of the root peel and leaves increased only at the highest compost treatments. At Corozal, leaf nitrogen concentrations were lower than those reported by others (Irizarry and Rivera, 1983; Rivera et al., 1985), and on that basis one could expect some kind of response to nitrogen additions from compost. However, the mineralization rate of this compost was estimated to be less than 5\% (data not shown); therefore, significant contributions of plant available nitrogen would occur only at very high rates (>100 t/ha). The leaf nitrogen content of plants grown at Corozal was significantly higher than that at Juana Díaz. In both soils the leaf nitrogen content of four-month-old plants was higher than at harvest (10 months) (data not shown).

As with nitrogen, only the highest compost treatments appeared to exert a significant influence on the phosphorus status of the cassava plants, although in most cases the contributions were not statistically significant. This finding contrasts with estimates of the plant-available 
J. Agric. Univ, P.R. vOL. 85, NO. 1-2, JANUARY-APRIL 2001

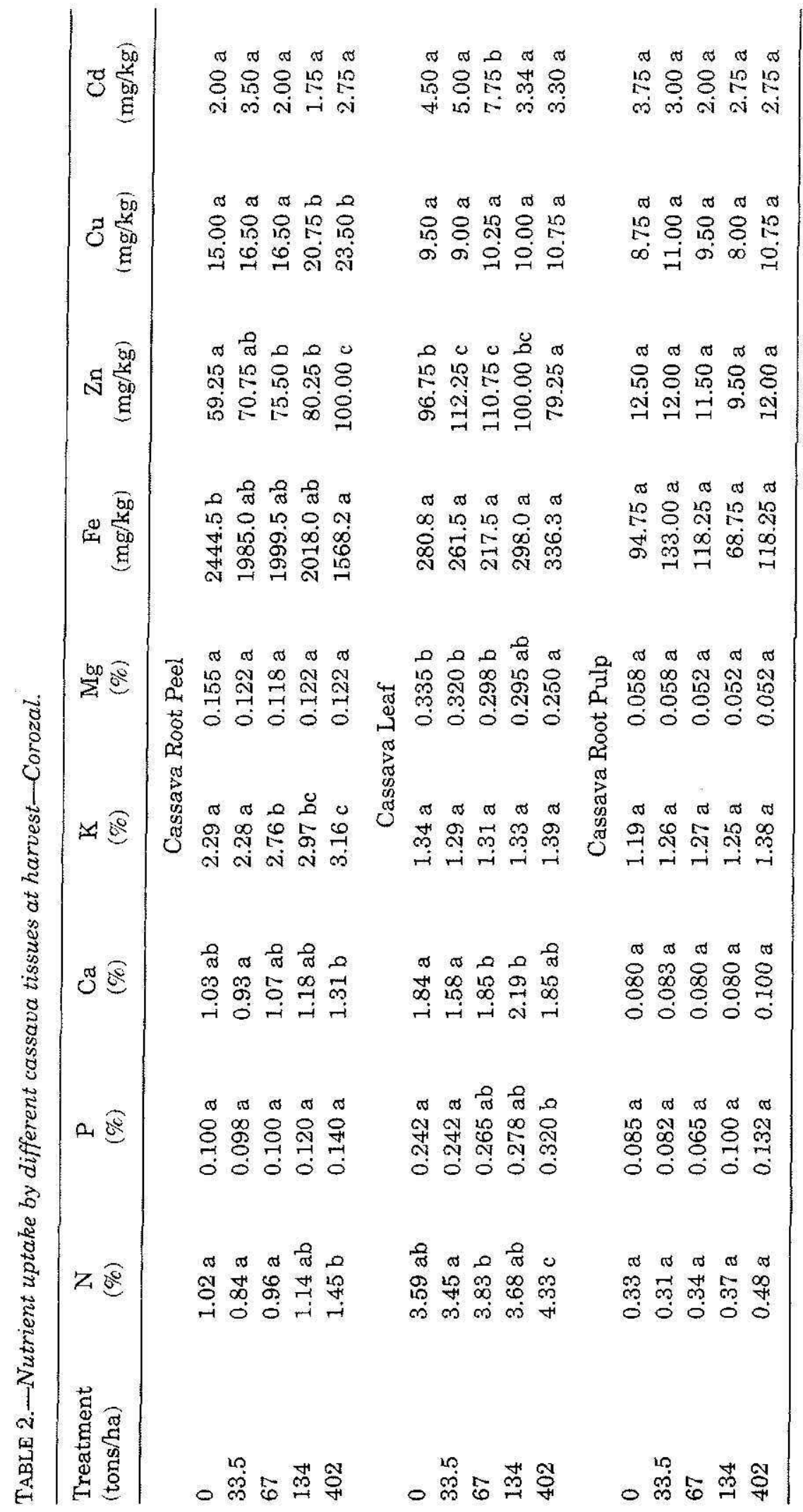




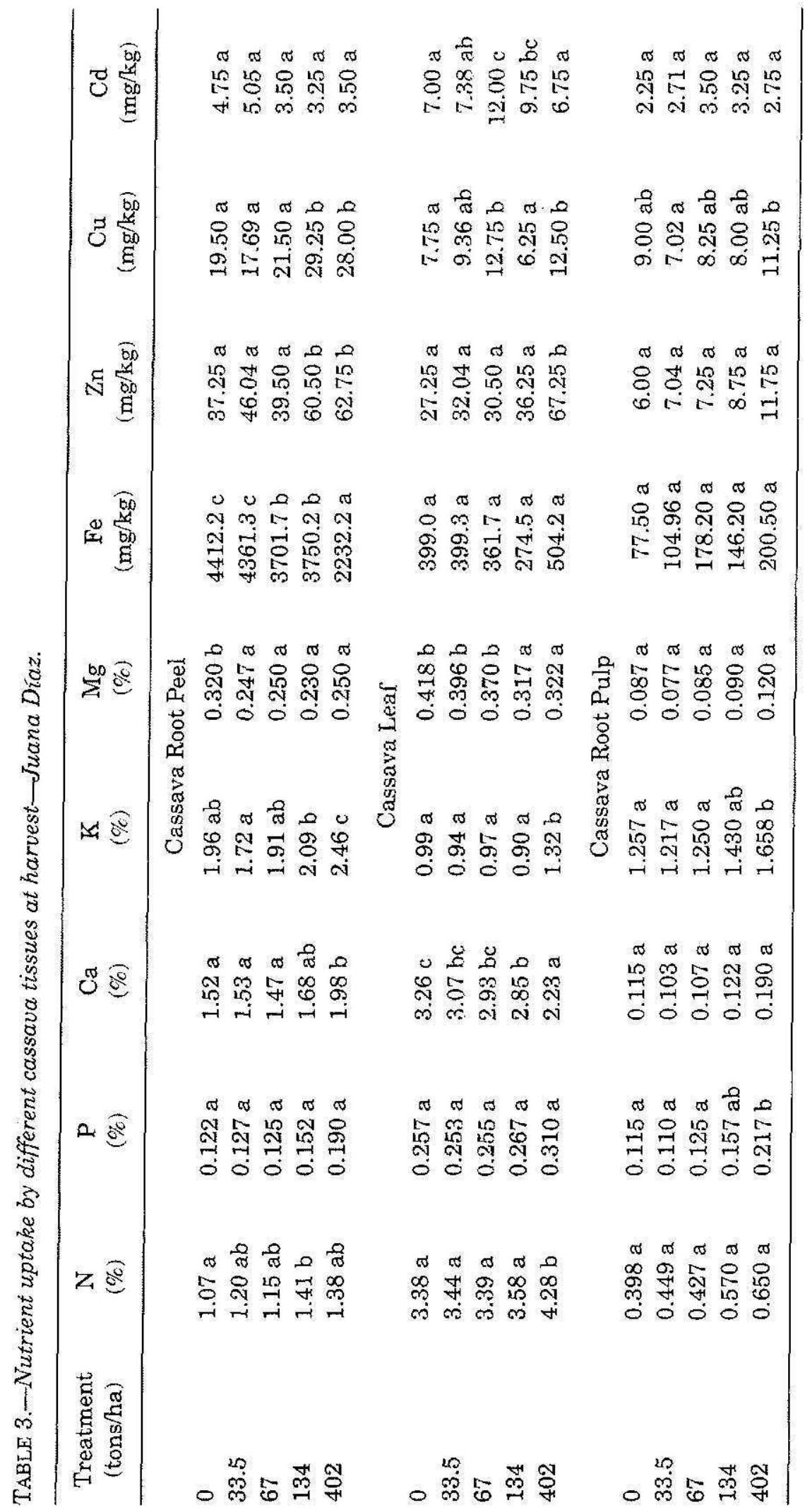


phosphorus fraction in those soils obtained from chemical analyses, which reflected a large increase from compost additions (Martínez et al., 1999). We are unable to determine whether the lack of response is due to an already adequate phosphorus nutritional status of the plants in the control treatment or whether the extractant used to estimate the plant-available soil phosphorus fraction overestimated that fraction. The phosphorus concentrations of plant leaves at Corozal were similar to or higher than those reported by other authors on this soil (Irizarry and Rivera, 1983; Rivera et al., 1985). As in the case of nitrogen, the phosphorus leaf content of four-month-old plants was higher than that of the ten-month-old plants (data not shown).

The effect of compost additions on calcium was more noticeable in the peel tissue, where a significant increase was observed at the highest compost treatment in both soils. The leaf calcium concentration showed practically no response in the Corozal soil but decreased in Juana Díaz at high compost rates. A similar effect was observed with potassium, where the cassava root peel and even the root pulp showed a stronger influence from the compost treatments than the leaves. These results agree with the findings of Howeler and Cadavid (1983), who reported a preferential distribution of potassium in the cassava roots relative to their apical portion. The root peel and leaf tissues at Corozal had a higher potassium content than at Juana Díaz. This finding is similar to what was observed with nitrogen, and even though in this case the level of soil exchangeable potassium in both soils was similar, the percentage saturation of the exchange complex in Corozal was significantly higher than in Juana Díaz (Martínez et al., 1999).

The effects of the sewage sludge compost on magnesium might appear surprising since tissue (leaf, root peel) concentrations tended to decrease with increasing compost. However, as stated in a previous paper (Martínez et al., 1999), even though the total amount of magnesium added to the soils increased with compost additions, there was a significant reduction in the soil exchangeable magnesium fraction of both soils. This situation appeared to reduce availability of magnesium to the plants, as was reflected in a corresponding decrease in the amount of leaf magnesium (Tables 2 and 3). The leaf and root pulp magnesium content of plants grown in Juana Díaz was higher than in those grown at Corozal. This finding is a reflection of the inherent magnesium content of the soils, as well as the relative percentage magnesium saturation of the exchange complex (Martínez et al., 1999).

Compost additions caused the iron content of the cassava root peel to decrease in both soils. The leaf iron concentration increased only at the highest treatment, although the difference was not statistically significant. The effects on the cassava pulp were highly variable and even 
though there was a trend toward an increase in concentration with compost additions, the differences were not statistically significant. Zinc increased in the cassava root peel and leaf tissue in both soils, except for the highest treatment in Corozal (leaf tissue), where the $\mathrm{pH}$ increase caused by that treatment may have limited the availability of zinc. The amount of zinc in all plant tissues was significantly lower in plants grown in Juana Díaz than in those grown at Corozal, in concordance with estimates of plant available levels of zinc in both soils. The amount of copper taken up by the plants also tended to increase with compost additions, especially in the root peel, where most of this element concentrates at harvest. Although copper is not hazardous to humans it may deteriorate surface and ground water resources and can be particularly harmful to the soil microbiota and some plants (McGrath et al., 1995; Krebs et al., 1998). Thus it is important to monitor its concentration in soils.

Cadmium is probably the element of most concern where products derived from sewage sludge are applied. The relative ease with which this element is taken up by most crops, its mobility in soils, as well as its effects on human health, are the main causes for concern. In this experiment, the amount of cadmium present in the compost was well below EPA established limits and thus there was little reason for concern. However, an important property is the equivalent distribution of this element among all crop tissues (Tables 2 and 3). This distribution differs from what was observed with other elements (e.g., nitrogen, calcium). It suggests that cadmium should be monitored extensively not only in edible leaf crops, as the current wisdom indicates, but also in crops such as cassava, a root crop whose edible tissue is in intimate contact with the soil for a prolonged period of time.

\section{Nutrient Distribution}

Nutrient distribution among the different cassava tissues (Figure 1) can be basically described by six broad categories. Regardless of crop age, nitrogen, phosphorus, magnesium, and calcium were mostly concentrated in the leaves according to the following patterns:

1) leaf $\gg>$ peel $\gg$ pulp (nitrogen and calcium)

2) leaf $>$ peel $>$ pulp (phosphorus and magnesium)

On the other hand, potassium and iron were mostly concentrated in the peel, exhibiting a much different pattern, namely:

3) peel $>$ leaf $\cong$ pulp (iron)

4) peel $>$ leaf $\cong$ pulp [potassium, copper (harvest)] 


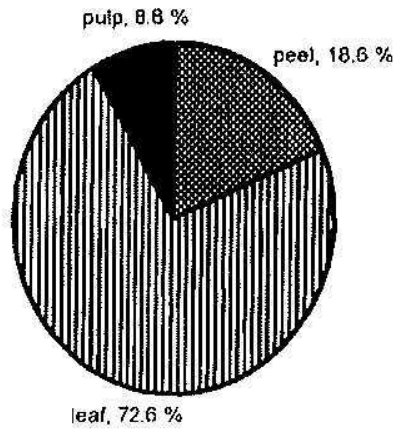

Nitrogen

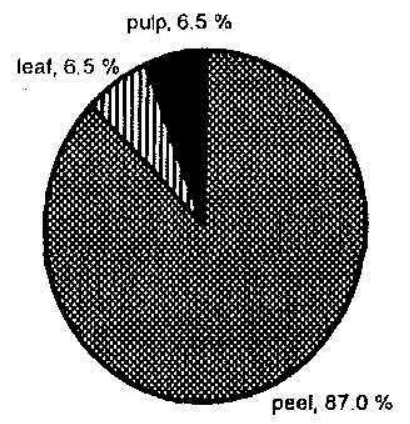

iron

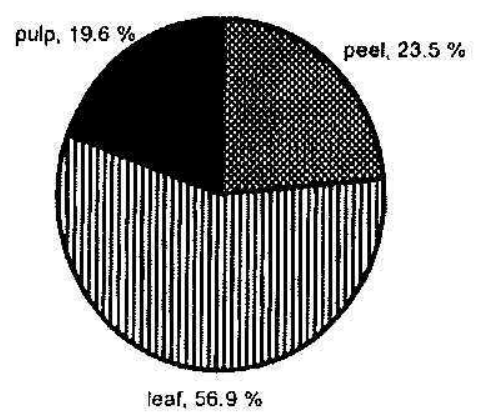

Phosphorus

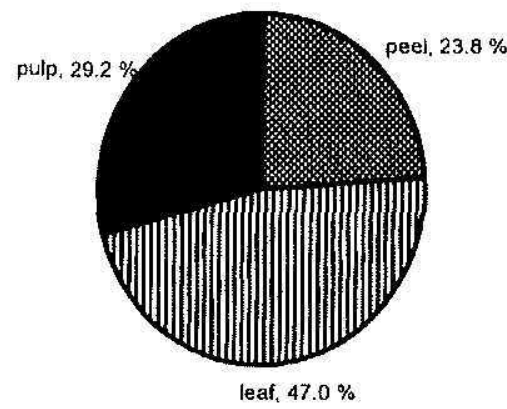

Cadmium

FIGURE 1. Nutrient distribution among different cassava plant tissues.

This distribution is important because those cations (i.e., potassium, iron) have some of the highest equivalent ionic conductivity in solution (Weast, 1986). They are the most responsible for the saline effect observed in the soil. Their tendency to concentrate in the cassava root peel may enhance the sensitivity of this crop to soil salinity, which would explain the deleterious effect of this compost on crop yield.

Among the trace elements, zinc exhibited a tendency to concentrate in the leaves, displaying the following distribution:

5) leaf $\geq$ peel $\gg>$ pulp [zinc, copper (four months)]

On the other hand, copper was the only element whose distribution among the different crop tissues varied significantly with crop age. At four months copper, similar to zinc, was mostly concentrated in the leaf; however, at harvest copper was mostly concentrated in the peel tissue, thus exhibiting a pattern similar to that of potassium. 
Cadmium was the only element whose concentration in the pulp tissue equaled or exceeded that of the peel and exhibited the following pattern:

6) leaf $\geq$ pulp $\geq$ peel (cadmium)

Again this finding points out the need to monitor cadmium in soils where cassava is to be grown.

\section{Relationship between Nutrient Uptake and Soil Parameters:}

Correlation analyses were carried out for both soils (pooled and separate) to assess the relevance of different soil parameters in terms of nutrient uptake by different crop tissues [For specific data on soil parameters, please refer to Martínez et al. (1999)]. Overall, strong correlations were found between soil and nutrient tissue level in each of the tissues evaluated, thus indicating that nutrient uptake responded to well defined conditions (Table 4). Except for calcium, macronutrient leaf concentration (i.e., phosphorus, magnesium and potassium) was highly correlated to estimates of the plant available fraction (i.e., Olsen P, and exchangeable K, and $\mathrm{Mg}$ ) in both soils combined. It is significant that in those cases similar relationships held for both soils despite their wide differences in chemical and mineralogical properties. In the case of micronutrients, the correlations between nutrient uptake and the different soil factors were not as marked as for the macronutrients. For the most part, data from each soil had to be considered separately to achieve an adequate description of element uptake. Micronutrient uptake is strongly influenced by the specific chemical conditions (e.g., $\mathrm{pH}$, ionic strength, soil organic matter content) of a particular system, all of which may preclude any attempt for a uniform description of data obtained from two very different soils, such as the ones used in this study.

The nutrient content of the root peel also exhibited a strong correlation with estimates of the soil available fraction in most cases, including copper and iron. In the case of iron, however, a negative correlation was found, thus indicating that whereas compost additions increased the EDTA available fraction of iron, said portion was unavailable to the crops. That unavailability could be the result of the formation of an iron containing solid phase at the high compost rates (high $\mathrm{pH}$, elevated total iron content) that could still be available for EDTA extraction but inaccessible for crop uptake. The nutrient content of the pulp did not exhibit the robust nature of the other plant tissues and required specific evaluation for each soil in order to obtain a highly significant correlation. As with the other plant tissues, the organic matter content of the soil proved to be a relevant parameter at Juana Díaz, whereas $\mathrm{CEC}, \mathrm{pH}$, and plant available fraction in the soil were the most significant factors in Corozal. 
TABLE 4.-Pearson's correlation coefficients for the most relevant relations between the nutrient content of various cassava tissues and different soil parameters.

\begin{tabular}{|c|c|c|c|c|}
\hline \multirow{2}{*}{$\begin{array}{l}\text { Plant } \\
\text { tissue }\end{array}$} & \multirow{2}{*}{$\begin{array}{l}\text { Plant } \\
\text { tissue } \\
\text { element }\end{array}$} & Corozal soil & Juana Díaz soil & Combined soils \\
\hline & & Soil parameter $(r)^{1}$ & Soil parameter $(r)$ & Soil parameter ( $r$ ) \\
\hline \multirow[t]{7}{*}{ Leaves } & $\mathrm{P}$ & $\operatorname{Trt}^{2}(0.98)$, CEC $(0.96), P(0.96)$ & $\mathrm{OM}(0.99), \operatorname{Tmt}(0.98), \mathrm{P}(0.98)$ & $\operatorname{Tmt}(0.97), \mathrm{OM}(0.93), \mathrm{P}(0.90)$ \\
\hline & $\mathrm{Ca}$ & - & $\begin{array}{l}\operatorname{Tmt}(-0.99), \mathrm{CEC}(-0.98) \\
\mathrm{Ca}(-0.98), \mathrm{OM}(-0.97)\end{array}$ & - \\
\hline & $\mathrm{Mg}$ & $\begin{array}{l}\mathrm{CEC}(-0.99), \operatorname{Tmt}(-0.95), \mathrm{pH}(-0.92) \\
\mathrm{Mg}(0.85)\end{array}$ & $\mathrm{CEC}(-0.89), \mathrm{pH}(0.79), \mathrm{Mg}(0.78)$ & $\operatorname{Mg}(0.79)$ \\
\hline & $\mathrm{K}$ & $\operatorname{Tmt}(0.87), \mathrm{OM}(0.87)$ & $\mathrm{K}(0.95), \mathrm{OM}(0.92), \operatorname{Tmt}(0.88)$ & $\mathrm{K}(0.88)$ \\
\hline & $\mathrm{Zn}$ & $\operatorname{Zn}(-0.84), 0 M(-0.84), \operatorname{Trnt}(-0.83)$ & $\mathrm{OM}(0.99), \operatorname{Tmt}(0.99), \mathrm{Zn}(0.97)$ & $\mathrm{pH}(-0.66)$ \\
\hline & $\mathrm{Fe}$ & $\mathrm{OM}(0.80)$ & - & $\operatorname{CEC}(0.64)$ \\
\hline & $\mathrm{Cu}$ & $\operatorname{CEC}(0.83), \operatorname{Tmt}(0.80)$ & - & - \\
\hline \multirow[t]{7}{*}{ Root peel } & $P$ & $\operatorname{Tmt}(0.96), \mathrm{P}(0.92), \mathrm{OM}(0.89)$ & $\begin{array}{l}\mathrm{P}(0.99), \operatorname{Tmt}(0.98), \mathrm{OM}(0.97) \\
\text { CEC }(0.93)\end{array}$ & $\mathrm{P}(0.90), \mathrm{CEC}(0.89)$ \\
\hline & $\mathrm{Ca}$ & $\operatorname{Tmt}(0.90), \mathrm{CEC}(0.85), \mathrm{Ca}(0.85)$ & $\begin{array}{l}\text { OM (0.97), Tmt }(0.97), \mathrm{pH}(-0.92) \text {, } \\
\mathrm{Ca}(0.88)\end{array}$ & $\mathrm{CEC}(0.85), \mathrm{Ca}(0.82)$ \\
\hline & $\mathrm{Mg}$ & $\mathrm{pH}(-0.80)$ & - & $\mathrm{Mg}(0.95)$ \\
\hline & $\mathrm{K}$ & $\operatorname{CEC}(0.87), \mathrm{pH}(0.86), \operatorname{Tmt}(0.84)$ & $\mathrm{pH}(-0.89), \mathrm{OM}(0.93)$, Tmt (0.92) & $\mathrm{K}(0.65)$ \\
\hline & $\mathrm{Zn}$ & $\begin{array}{l}\mathrm{CEC}(0.99), \operatorname{Tmt}(0.96), \mathrm{pH}(0.95), \\
\mathrm{Zn}(0.92)\end{array}$ & $\mathrm{pH}(-0.90), \mathrm{Zn}(0.83), \mathrm{CEC}(0.83)$ & - \\
\hline & $\mathrm{Fe}$ & $\operatorname{CEC}(-0.95), \mathrm{pH}(-0.94), \operatorname{Tmt}(-0.87)$ & $\begin{array}{l}\mathrm{Fe}(-0.98) \text {, Tmt }(-0.98) \text { OM }(-0.97) \\
\text { CEC }(-0.97)\end{array}$ & $\mathrm{Fe}(-0.88)$ \\
\hline & $\mathrm{Cu}$ & $\begin{array}{l}\operatorname{Tmt}(0.94), \mathrm{pH}(0.90), \mathrm{CEC}(0.89) \text {, } \\
\mathrm{Cu}(0.86)\end{array}$ & $\mathrm{PH}(-0.88), \mathrm{CEC}(0.83)$ & $\mathrm{CEC}(0.86), \mathrm{Cu}(0.79)$ \\
\hline
\end{tabular}


TABLE 4.-(Continued) Pearson's correlation coefficients for the most relevant relations between the nutrient content of various cassava tissues and different soil parameters.

\begin{tabular}{|c|c|c|c|c|}
\hline \multirow{2}{*}{$\begin{array}{l}\text { Plant } \\
\text { tissue }\end{array}$} & \multirow{2}{*}{$\begin{array}{l}\text { Plant } \\
\text { tissue } \\
\text { element }\end{array}$} & Corozal soil & Juana Díaz soil & Combined soils \\
\hline & & Soil parameter $(r)^{1}$ & Soil parameter $(r)$ & Soil parameter ( $r$ ) \\
\hline \multirow[t]{7}{*}{ Root pulp } & $\mathrm{P}$ & $\operatorname{Tmt}(0.89), \mathrm{P}(0.87), \mathrm{OM}(0.86)$ & $\mathrm{P}(0.99), \mathrm{OM}(0.98), \operatorname{Tmt}(0.98)$ & $\mathrm{P}(0.87)$ \\
\hline & $\mathrm{Ca}$ & $\mathrm{OM}(0.95), \operatorname{Tmt}(0.86)$ & $\mathrm{OM}(0.99), \operatorname{Tmt}(0.97), \mathrm{Ca}(0.87)$ & $\mathrm{CEC}(0.79), \mathrm{Ca}(0.78)$ \\
\hline & $\mathrm{Mg}$ & $\operatorname{Mg}(0.96)$ & $\mathrm{OM}(0.98), \mathrm{Mg}(-0.96)$ & $\operatorname{Mg}(0.75)$ \\
\hline & $\mathrm{K}$ & CEC (0.98), Tmt (0.92), OM (0.92) & Tint $(0.96), \mathrm{OM}(0.95), \mathrm{pH}(-0.95)$ & $\mathrm{OM}(0.81), \operatorname{Tmt}(0.80)$ \\
\hline & $\mathrm{Zn}$ & - & $\begin{array}{l}\mathrm{Zn}(0.99), \operatorname{Tmt}(0.99), \mathrm{OM}(0.97) \\
\text { CEC }(0.97)\end{array}$ & - \\
\hline & $\mathrm{Fe}$ & - & $\operatorname{CEC}(0.90), \mathrm{Fe}(0.80)$ & $\operatorname{CEC}(0.64)$ \\
\hline & $\mathrm{Cu}$ & - & $\mathrm{OM}(0.87) . \mathrm{Cu}(0.83)$ & $\mathrm{OM}(0.69)$ \\
\hline
\end{tabular}

${ }^{1} \mathrm{r}$ refers to correlation coefficient.

'Tmt refers to tons/ha of compost added. 
An analysis of stepwise regression was performed with both soils combined to ascertain the relation between several soil components and the nutritional status of the plants at harvest. Highly significant relations were obtained for most elements, indicating that there is a strong relation between the chemical conditions of a particular soil and the amount of nutrients taken up by the crops (Table 5 ).

\section{CONCLUSIONS}

Additions of compost at high rates ( $402 \mathrm{t} / \mathrm{ha}$ ) caused a significant reduction in cassava yield in Corozal, but had no effect in Juana Díaz. The number of non-commercial roots increased in the compost treatments relative to the control. It is suspected that such results are a reflection of the impact of the particular compost on soil salinity and the consequent impact of soil salinity on crop performance.

The nutritional status of the cassava plants was not appreciably altered by the compost. Significant increases in the amount of nitrogen, phosphorus, and potassium taken up by the plants occurred only at the highest treatments. On the other hand, a reduction in the concentration

TABLE 5.-Relationship among the nutrient content of cassava grown on two soils and various soil parameters.

\begin{tabular}{|c|c|}
\hline Plant mutrient & Crop tissue, equation, and coefficient of determination \\
\hline Phosphorus & $\begin{array}{l}\text { Peel } P=0.137+\text { soil } P(0.005)-O . M .(0.20)-C E C(0.0017), R^{2}=0.956 \\
\text { Leaf } P=0.2475+(\text { tons/acre compost } 0.00037), R^{2}=0.94 \\
\text { Pulp } P=0.197+\text { soil } P(0.0062)-O . M .(0.029)-p H(0.0178), R^{2}=0.93\end{array}$ \\
\hline Calcium & $\begin{array}{l}\text { Peel Ca }=0.4379-\text { soil Ca }(0.158)+\operatorname{CEC}(0.175), \mathrm{R}^{2}=0.869 \\
\text { Leaf } \mathrm{Ca}=1.22-\text { soil Ca }(0.3049)-\text { O.M. }(0.1757)+\mathrm{CEC}(0.3362), \\
\mathrm{R}^{2}=0.88\end{array}$ \\
\hline Magnesium & $\begin{array}{l}\text { Peel } \mathrm{Mg}=0.0858+\text { soil } \mathrm{Mg}(0.0593), \mathrm{R}^{2}=0.90 \\
\text { Leaf } \mathrm{Mg}=0.319+\text { soil } \mathrm{Mg}(0.045)-\mathrm{CEC}(0.0024), \mathrm{R}^{2}=0.90 \\
\text { Pulp } \mathrm{Mg}=0.0697+\text { soil } \mathrm{Mg}(0.0218)+\mathrm{O} . \mathrm{M} .(0.0064)-\mathrm{pH}(0.0084) \\
\mathrm{R}^{2}=0.87\end{array}$ \\
\hline Potassium & $\begin{array}{l}\text { Peel } K=1.64+\text { soil } K(1.214)-O . M .(0.426)+(\text { tons/acre compost } \\
\text { Leaf } K=1.54-\text { CEC }(0.021)+\left(\text { tons/acre compost }{ }^{2}=0.004\right), R^{2}=0.92 \\
\text { Leaf }\end{array}$ \\
\hline Zine & $\begin{array}{l}\text { Pulp } \mathrm{Zn}=20.53+\text { O.M. }(0.785)-\mathrm{pH}(1.93), \mathrm{R}^{2}=0.88 \\
\text { Pulp } \mathrm{Zn}=23.39-2.21(\mathrm{pH})+(\text { tons/acre compost } 0.0297), \mathrm{R}^{2}=0.89\end{array}$ \\
\hline Iron & Peel Fe $=4556.74-$ soil Fe (0.98) - O.M. (165.9), $R^{2}=0.90$ \\
\hline Copper & Peel $\mathrm{Cu}=11.23+\mathrm{CEC}(0.33), \mathrm{R}^{2}=0.74$ \\
\hline Cadmium & Leaf $\mathrm{Cd}=17.82-$ O.M. $(1.75)+0.51(\mathrm{CEC})-2.90(\mathrm{pH}), \mathrm{R}^{2}=0.89$ \\
\hline
\end{tabular}


of iron and magnesium was observed with the addition of compost. Both copper and zinc increased, whereas cadmium was minimally affected, thus reflecting the low amount of this element in the compost. Strong correlations were found between the amount of nutrients in different plant tissues and various soil parameters, thus indicating that the nutritional status of the plants responded to well defined conditions.

A nutrient distribution analysis revealed that regardless of crop age, nitrogen, phosphorus, magnesium, calcium, and zinc were concentrated mostly in the leaves, whereas potassium and iron were concentrated mostly in the root peel. This finding is significant since such a pattern may explain the sensitivity of this crop to soil salinity. Cadmium was the only element whose concentration in the root pulp tissue equaled or exceeded that in the root peel, all of which points out the necessity of monitoring the concentration of cadmium in soils where cassava is to be grown.

\section{LITERATURE CITED}

Agricultural Experiment Station, 1997. Conjunto Tecnológico para la producción de Raíces y Tubérculos. Publication 101.

Dumas, J. A., 1989. Manual de Procedimientos del Laboratorio Central Analítico, Estación Experimental Agrícola, R.U.M.

Fox, R. H., H. Talleyrand and T. W. Scott, 1975. Effect of nitrogen fertilization on yields and nitrogen content of cassava, Llanera cultivar. J. Agric. Univ. P.R. 59(2):115-124.

Howeler, R. H. and L. R. Cadavid, 1983. Accumulation and distribution of dry matter and nutrients during 12 months growth cycle of cassava. Field Crop Research. $7: 325-340$.

Hulugalle, N. R., R. Lal and M. Gichuru, 1990. Effect of five years of no-tillage and mulch on soil properties and root yield of cassava on an acid Ultisol in south-eastern Nigeria. Expl. Agric. 26:235-240.

Irizarry, H. and E. Rivera, 1983. Nutrient and dry matter contents of intensively managed cassava grown on an Ultisol. J. Agric. Univ. P.R. 67(3):213-220.

Krebs, R., S. K. Gupta, G. Furrer and R. Schulin, 1998. Solubility and plant uptake of metals with and without liming of sludge-amended soils. J. Environ. Qual. 27:18-23.

McBride, M. B., 1995. Toxic metal accumulation from agricultural use of sludge: Are USEPA regulations protective?. J. Environ. Qual. 24:5-18.

McGrath, S. P., A. M. Chaudri and K. E. Giller, 1995. Long-term effects of metals in sew. age sludge on soils, microorganisms and plants. J. Indust. Microbiol. 14:94-104.

Martínez, G. A., J. L. Guzmán, M. A. Vázquez, L. E. Rivera and A. González, 1999. Chemical and physical properties of two tropical soils treated with sewage sludge compost. J. Agric. Univ. P.R. 83(3-4):103-121.

Rivera, E., F. Abruña, and José Rodríguez, 1985. Crop response to soil acidity factors in Ultisols and Oxisols in Puerto Rico XI. Cassava. J. Agric. Univ. P.R. 69(2):145-151.

Samuels, G., 1969. The influence of fertilizer levels and sources on cassava production on a Lares clay in Puerto Rico, Caribbean Food Crops Soc. Proc. (MartiniqueGuadeloupe) 7: 33-6.

U.S. Environmental Protection Agency, 1993. Clean Water Act. Section 503. 58(32). USEPA, Washington, DC.

Weast, R. C. (ed), 1986. CRC Handbook of Chemistry and Physics. CRC Press, Inc. 